Мацкевич Ю.І.,

к.е.н., старший викладач кафедри економічної теорії та підприємництва,

ДВНЗ «Приазовський державний технічний університет»

ORCID: 0000-0002-2602-6175

matskevich_yuliy@ukr.net

\title{
БІЗНЕС-ПЛАНУВАННЯ ЯК ІНСТРУМЕНТ ФІНАНСОВОЇ СТІЙКОСТІ ПІДПРИЄМСТВА В УМОВАХ НЕСТАБІЛЬНОСТІ УКРАЇНСЬКОЇ ЕКОНОМІКИ
}

У період економічної та фінансової нестабільності в Україні першочерговим завданням є планування діяльності суб'єктів господарювання в мінливих умовах економічного розвитку країни. У сформованій ситуації необхідний особливий підхід до організації процесу прийняття оптимальних управлінських рімень $i$ пошук інструментів, здатних забезпечити їх реалізацію. Низька рентабельність $i$ платоспроможність, малоефективна грошово-кредитна політика $i$ система оподаткування, відсутність відповідної законодавчої бази $і$ дієвих механізмів регулювання грошових потоків є результатом фінансової нестабільності. Для забезпечення фінансової стійкості необхідна побудова ефективно діючої в умовах, щзо склалися схеми управління підприємством. У бізнес-плані підприємства повинні знайти відображення всі фактори, які впливають на його функціонування, і перш за все, Бізнес-планування повинно забезпечувати вирішення питань щодо поліпшення фінансового стану підприємства. У зв'язку з цим у статті велика увага приділяється питанням підвищення результативності фінансового управління у складі бізнеспланування. Стаття має науково-методичний характер.

Ключові слова: економічна нестабільність, бізнес-планування, фінансовий план, фінансова стійкість.

Літ. - 11

Мацкевич Ю.И.,

к.э.н., старший преподаватель кафедры экономической теории и предпринимательства,

ГВУЗ «Приазовский государственный технический університет»

ORCID: 0000-0002-2602-6175

matskevich_yuliy@ukr.net

\section{БИЗНЕС-ПЛАНИРОВАНИЕ КАК ИНСТРУМЕНТ ФИНАНСОВОЙ УСТОЙЧИВОСТИ ПРЕДПРИЯТИЯ В УСЛОВИЯХ НЕСТАБИЛЬНОСТИ УКРАИНСКОЙ ЭКОНОМИКИ}

В период экономической $и$ финансовой нестабильности в Украине первоочередной задачей является планирование деятельности субъектов хозяйствования в изменчивых условиях экономического развития страны. В сложившейся ситуации необходим особый подход к организации процесса принятия 
оптимальных управленческих решений и почск инструментов, способных обеспечить их реализацию. Низкая рентабельность и платежеспособность, малоэффективная денежно-кредитная политика и система налогообложения, отсутствие соответствующей законодательной базы и действенных механизмов регулирования денежных потоков являются результатом финансовой нестабильности. Для обеспечения финансовой устойчивости необходимо построение эффективно действуюшей в сложившихся условиях схемы управления предприятием. В бизнесплане предприятия должны найти отражение все факторы, которые влияют на его функиионирование, и прежде всего, бизнес-планирование должно обеспечивать решение вопросов по улучшению финансового состояния предприятия. В связи с этим в статье большое внимание уделяется вопросам повышения результативности финансового управления в составе бізнес-планирования. Статья имеет научнометодический характер.

Ключевые слова: экономическая нестабильность, бизнес-планирование, финансовый план, финансовая устойчивость.

Лит. - 11

\section{Yu. Matskevich,}

$\mathrm{Ph}$. D, Senior Lecturer of the Department of Economic Theory and Entrepreneurship, State University «Priazovsky State Technical University»

ORCID: 0000-0002-2602-6175

matskevich_yuliy@ukr.net

\section{BUSINESS PLANNING AS A TOOL OF FINANCIAL STABILITY ENTERPRISE IN THE CONDITIONS INSTABILITY OF THE UKRAINIAN ECONOMY}

During the period of economic and financial instability in Ukraine, the first priority is to plan the activities of business entities in the changing conditions of the country's economic development. In this situation, a special approach to organizing the process of making optimal management decisions and finding tools that can ensure their implementation is necessary. Low profitability and solvency, inefficient monetary policy and tax system, lack of an appropriate legislative framework and effective mechanisms for regulating cash flows are the result of financial instability. To ensure financial stability, it is necessary to build an effective enterprise management scheme that operates in the current conditions. The business plan of the enterprise should reflect all the factors that affect its functioning, and first of all, business planning should provide solutions to issues related to improving the financial condition of the enterprise. In this regard, the article pays great attention to improving the effectiveness of financial management as part of business planning. The article is of a scientific and methodological character.

Keywords: economic instability, business planning, financial plan, financial stability. Ref. -11

Актуальність проблеми. В бізнес-плані кожен з аспектів має свої особливості і специфіку відображення, яка визначається конкретними завданнями діяльності підприємства в цілому і його окремих підрозділів. Повнокровне функціонування підприємства неможливо без урахування всіх цих сторін діяльності. Фінансовий менеджмент виступає ключовою підсистемою загальної системи управління завдяки вирішенню такіх завдань, як забезпечення платоспроможності та фінансової стійкості 
підприємства, організації управління фінансовою діяльністю в цілому. Але найменш розробленим з усіх розділів бізнес-плану, справедливо вважається фінансовій план. Тому сьогодні $є$ актуальним і необхідним аналіз і використання різних форм і методів фінансового планування з урахуванням необхідності досягнення стійкості діяльності підприємств і відповідно до підрозділів фінансового плану.

Аналіз останніх досліджень і публікацій. Проблеми бізнес-планування та його вплив на стійкість і розвиток підприємства є предметом дослідження таких науковців, як: В.Р. Кучеренко, В.В Македон [1], Л.Т. Агафонова, І.І. Циглик, Г. Я. Аніловська [2], Г. О. Швиданенко [3], В. О. Козловський, І.3. Должанський [10] та інші. Однак сьогодні деякі аспекти розробки таких розділів бізнес-плану, як фінансовий план, залишаються дискусійними і потребують уточнення.

Мета статті - проаналізувати роль і значення бізнес-планування для українських підприємств у підвищенні рівня фінансової стійкості.

Виклад основного матеріалу. Як відомо, для залучення інвесторів до фінансування різних виробничих проектів керівництво підприємства повинно переконати їх в існуванні реальної програми реалізації проектів, в наявності у підприємства шансів на комерційний успіх, забезпечення достатнього рівня прибутковості. Тільки на цій основі можна будувати взаємовигідні господарські та фінансові відносини з постачальниками, посередниками в реалізації готової продукції підприємства, 3 іншими партнерами. Програмою дій підприємця, необхідним інструментом проектно-інвестиційних рішень і внутрішньофірмового планування, який використовується у всіх сферах підприємництва $є$ бізнес-план. Він актуальний як для новостворюваних підприємств, так і для підприємств, які вже працюють [1, с. 5].

При складанні бізнес-плану важливо мати на увазі одну обставину, що випливає з аналізу зарубіжного досвіду в цій галузі. Цей досвід свідчить, що розробка бізнеспланів здійснюється, як правило, із залученням фахівців, експертів і консультантів. I це вітається інвесторами. Однак менеджери самої компанії (включаючи і керівництво) повинні брати в складанні бізнес-плану найактивнішу участь. Багато зарубіжних інвестиційних і фінансових компаній, банки взагалі відмовляються розглядати заявки на інвестування, якщо їм стає відомо, що бізнес-план підготовлений фахівцями з боку, а керівник підприємства його тільки підписав. 3 точки зору інвесторів і кредиторів, особиста участь керівників вищого рівня управління підприємством означає їх готовність відповідати за успішну реалізацію проекту, виконувати взяті зобов'язання.

Ключовою підсистемою загальної системи управління підприємством виступає фінансовий менеджмент, за допомогою якого вирішуються такі завдання, як: пошук джерел фінансування діяльності та визначення їх оптимальних розмірів, забезпечення платоспроможності та фінансової стійкості підприємства, організація управління фінансовою діяльністю в цілому. При цьому фінансове управління, зокрема планування в умовах перехідної економіки, має свої відмінні риси. Фінансовий менеджмент включає в себе такі цілі: максимізацію прибутку і мінімізацію доходів, виживання або досягнення лідерства в конкурентній боротьбі, збільшення так званої ринкової вартості підприємства та ін. I, частіше західні, бізнесмени прагнуть до оптимізації прибутку, до досягнення прийнятної для даного бізнесу величини.

В останні роки на Заході великого поширення набуває теорія, пов'язана 3 орієнтацією на максимізацію цінності підприємства, що виходить 3 передумови, що ні прибуток, ні рентабельність, ні обсяг виробництва не має права розглядатися в якості критерію ефективності діяльності підприємства, його фінансового управління. 
В його основі лежать концепції, що базуються на обгрунтуванні взаємозв'язку економічних і соціальних факторів суспільного розвитку, значимість яких стає очевидною в умовах розвинених ринкових відносин. В Україні повинна існувати своя специфіка фінансового управління, що обумовлюється необхідністю виживання $\mathrm{i}$ забезпечення можливості сталого розвитку для підприємств навіть в умовах високої економічної нестабільності. В області фінансового менеджменту є той факт, що в зарубіжній практиці пріоритет віддається звіту про прибутки і збитки, проте в українських умовах в якості основного документа фінансового плану традиційно продовжує розглядатися баланс активів і пасивів. Причини цього слід шукати в тому, що прибуток, так чи інакше, виступає одним з найважливіших показників діяльності західної компанії. Це глибоко вкоренилося в психології зарубіжного бізнесу, і саме його прагнуть продемонструвати стороннім спостерігачам як свідчення успішності комерційної діяльності.

У країнах 3 розвиненою ринковою економікою досягнення стабільності діяльності виявляється можливим при вкладенні в нову справу мінімуму власних коштів 3 переважним використанням кредитів, тобто знаходження можливості ризикувати «чужими коштами». Так, наприклад, для японських фірм характерно, що частка залученого капіталу становить $80 \%$ від використовуваного, в США його розмір досягає 60\%. При цьому джерелом позикових коштів в Японії є переважно банки, в США - грошові кошти населення. Подібний підхід не представляється можливим для української економіки 3 багатьох причин. По-перше, нерозвинена система кредитування. По-друге, перекіс структури коштів у бік позикових таїть загрозу банкрутства підприємства, так як «незручний час» для повернення коштів може настати раптово, в тому числі внаслідок «інфляційного стрибка». I по-трете, сама інфляція не може бути величиною більш-менш постійною в країні, де нестабільна i нерозвинена структура виробництва. В українських умовах характеристикою абсолютної фінансової стійкості може виступати ситуація, коли всі запаси покриваються власними оборотними коштами [2, с. 17]. Частково дані проблеми можна вирішити організаційним шляхом, зокрема створенням холдингів, в рамках яких здійснюється внутрішнє кредитування і забезпечується певна ступінь стійкості спільної діяльності. Але уникнути необхідності залучення зовнішніх кредитів, тим не менш, не завжди вдається.

3 усіх розділів бізнес-планів, що складаються вітчизняними підприємствами, найменш розробленим справедливо вважається фінансовий план. У той же час саме в цьому розділі бізнес-плану відображається реальний фінансовий стан підприємства, його доходи і витрати, розрахункі з партнерами, структурні зміни активів і пасивів; розробляються прогнози фінансових результатів діяльності підприємства, визначаються джерела фінансування та його потреби в додаткових фінансових ресурсах, формується модель дисконтованих грошових потоків, встановлюється точка беззбитковості (поріг рентабельності). Фінансовий розділ бізнес-плану дає можливість керівництву вибрати найкращий варіант рішення, мінімізувати наслідки ризику, пов'язаного 3 виконанням інвестиційної або інших програм розвитку підприємства [2, с. 136]. Тому забезпечення фінансової стійкості діяльності у вітчизняних умовах не виключає можливості використання наступних, традиційних для ринкової економіки, показників [4, с. 238]:

- коефіцієнт концентрації власного капіталу, коефіцієнт фінансової залежності, зворотний першому, а також коефіцієнт співвідношення власних і позикових коштів. Всі ці три показники характеризують фінансову стійкість діяльності при використанні 
позикових коштів. При цьому очевидно, що чим більшу частку використовуваного капіталу становить власний, тим стійкіше діяльність підприємства, але і ймовірніше отримання зовнішніх позик;

- коефіцієнт маневреності власного капіталу, що характеризує розподіл власного капіталу на статті: фінансування поточної діяльності та капіталізації.

Досягнення фінансової стійкості багато в чому визначається грамотністю вкладення коштів у власні активи, які за своєю природою досить динамічні і в процесі діяльності можуть зазнавати значних змін. Інформацію про динаміку подібних змін можна отримати, використовуючи вертикальний і горизонтальний аналіз фінансової звітності [5, с. 214]. Вертикальний аналіз дає уявлення про структуру фінансових коштів, включаючи джерела їх отримання, в рамках якого за допомогою використання відносних показників на основі балансу стає можливим проводити порівняння економічного потенціалу підприємства 3 результатами його діяльності, а також коригувати дані з урахуванням інфляційних змін. За допомогою горизонтального аналізу проводиться порівняння окремих показників балансу по ряду минулих років, що не виключає і можливості побудови прогнозів. Вибір показників, за якими потрібно провести аналіз, а також необхідність їх укрупнення здійснюється відповідно до аналітичних цілей. Але горизонтальний аналіз зазвичай не дає великого ефекту при високій інфляції. Якщо вертикальний аналіз «дозволяє відстежувати і прогнозувати структурні зрушення у складі господарських засобів і джерел їх покриття», то горизонтальний надає можливість «виявити тенденції зміни окремих статей або їх груп, що входять до складу бухгалтерської звітності. Цінність обох видів аналізу збільшується за умови їх взаємодоповнюваності і особливо важлива при проведенні зіставлень звітності різних за видом діяльності та обсягом виробництва. Збільшення активної частини основних засобів свідчить зростання фінансової стійкості діяльності, при цьому підприємство повинно прагнути і до зміцнення своєї матеріально-технічної бази.

В силу нестабільності української економіки, зміни порядку розрахунків і кредитування комерційних підприємств, істотної дебіторської та кредиторської заборгованості, несвоєчасності здійснення платежів великого значення набуває оперативне фінансове планування. Його зростаюче значення обумовлено необхідністю визначення послідовності і термінів проведення грошових операцій при оптимальному використанні фінансових ресурсів з метою отримання максимального економічного результату. Цей вид планування включає складання i виконання платіжного календаря, податкового календаря і касового плану. Платіжний календар підприємства визначає забезпеченість за рахунок усіх грошових ресурсів виконання підприємством своїх зобов'язань за платежами. Він складається за всіма статтями грошових надходжень і витрат, що проходять через відповідні рахунки в комерційних банках. При цьому береться до уваги законодавчо встановлена черговість списання грошових коштів 3 розрахункового рахунку господарюючого суб'єкта. Частиною платіжного календаря є податковий календар, який дозволяє контролювати терміни сплати податків та інших обов'язкових платежів і своєчасно надавати звітність до податкових органів, органів статистики та позабюджетних фондів.

Важливу роль у підвищенні платоспроможності підприємства відіграють касовий план і контроль за його виконанням. Він відображає надходження і виплати готівкових грошових коштів через касу господарюючого суб'єкта. 3 використанням даних балансу стає можливим проводити аналіз ліквідності підприємства, тобто його здатності відповідати власним поточним зобов'язанням. Критерії ліквідності, а також 
платоспроможності дозволяють оцінювати фінансовий стан в умовах, коли довгострокове планування виявляється нереальним. Платоспроможність і ліквідність - характеристики досить різні. Розраховані за ними коефіцієнти надають різну інформацію, але однаково необхідну для оцінки ефективності діяльності підприємства в умовах перехідної економіки. Вони можуть свідчити про «здоров'я» суб'єкта господарювання, а при спільному аналізі балансу і звіту про прибуток дозволяють найбільш об'єктивно оцінити саму діяльність. 3 їх допомогою стає можливим також проводити порівняння поточних показників 3 прогнозними або досягнутими в минулому.

Ліквідність передбачає наявність у підприємства достатніх оборотних коштів для погашення короткострокових зобов'язань, платоспроможність же передбачає можливість негайного погашення кредиторської заборгованості за рахунок наявних у підприємств грошових коштів або їх еквівалентів. Розрахунок різних показників ліквідності базується на порівнянні поточних активів 3 короткостроковими пасивами. При цьому більш точний і змістовний його аналіз може проводитися з використанням коефіцієнтів поточної або термінової ліквідності. Ступінь ліквідності підприємства виражається в коефіцієнті поточної ліквідності (Кпл), який характеризує загальну забезпеченість підприємства оборотними коштами для ведення господарської діяльності і визначається як співвідношення поточних активів (ПА) i короткострокових пасивів (КП).

$$
\text { Кпл }=\frac{\Pi A}{\kappa \Pi},
$$

Даний коефіцієнт, який може вважатися основним показником ліквідності, відображає обсяг фінансових коштів, що припадають на грошову одиницю фінансових зобов'язань. Його нормативна величина повинна знаходитися в діапазоні від 1,5 до 2, при цьому позитивно оцінюється динаміка його зростання. Коефіцієнт строкової ліквідності розраховується за вирахуванням частини поточних активів, тому може використовуватися в інших сферах діяльності.

Задовільність структури балансу також визначається коефіцієнтом забезпеченості власними оборотними коштами (Кок) і коефіцієнтом відновлення (втрати) платоспроможності (Квп), що визначаються за такими формулами:

де Вок - власні оборотні кошти;

$$
\text { Кок }=\frac{\mathrm{Bo \kappa}}{\mathrm{OK}_{3}} \text {, }
$$

ОКз - величина всіх оборотних коштів підприємства.

$$
\text { Квп }=\frac{\text { Кпл }_{1}}{\text { Кпл }}
$$

де Кпл1- деяке нормативне значення коефіцієнта поточної ліквідності, порівнюваного з прогнозованою його величиною.

Обидва коефіцієнти можуть вважатися характеристиками фінансової стійкості діяльності підприємства, при цьому коефіцієнт забезпеченості власними оборотними коштами вказує на частку власних коштів в їх обороті, а коефіцієнт відновлення (втрати) оцінюе можливість відновлення (або втрати) платоспроможності підприємства протягом прогнозованого періоду діяльності. Показники поточної ліквідності, забезпеченості власними оборотними коштами і здатності до відновлення платоспроможності, являють собою систему критеріїв для визначення структури балансу згідно з прийнятим законодавством про банкрутство [6] i дозволяють здійснювати прогнозування можливості його настання. Саме на підставі розрахунку 
даних коефіцієнтів приймаються рішення про те, чи можна вважати структуру балансу задовільною, а саме підприємство платоспроможним і ефективно діючим.

У світлі нового податкового законодавства особливої актуальності набувають методи регулювання фінансових результатів, які дозволяють легально існуючими в рамках чинного законодавства і нормативних документів [7] способами знижувати податки. Можливість варіювання фінансовими результатами досягаються за допомогою таких методів, як:

- зміна меж нормативу віднесення активу до основних засобів, що дозволяє змінювати величину поточних витрат, а значить і прибутку;

- здійснення періодичної переоцінки основних засобів, включаючи використання понижуючих коефіцієнтів до амортизаційних відрахувань;

- використання прискореної амортизації активної частини основних виробничих фондів;

- застосування різних методів обліку виробничих запасів, вибір яких здійснюється самим підприємством, а його результати позначаються на величині прибутку;

- оцінка переданого в натуральній формі майна до статутного капіталу на розсуд договірних сторін;

- самостійне визначення величини оцінки нематеріальних активів і методів їх амортизації, критеріїв для створення резерву за сумнівними боргами;

- вибір порядку обліку відсотків за банківськими кредитами (якщо такі є), що дозволяє варіювати фінансові результати діяльності, їх відображення в статтях балансу; методів списання малоцінних і швидкозношуваних предметів; порядку віднесення окремих видів витрат на собівартість реалізованої продукції та ін.

Bci перераховані вище методи грунтуються на складанні балансу. Ознаками «хорошого» балансу [8, с. 29], що дозволяє говорити про ефективність діяльності підприємства, прийнято вважати наступні:

- забезпеченість власним капіталом, що поєднується із зростанням його частки;

- рівновага за окремими статтями балансу, а дебіторської заборгованості - 3 розмірами кредитного боргу;

- у балансі відсутні збитки, прострочені заборгованості та інші «хворі» статті;

- запаси і витрати не перевищують мінімальних джерел їх покриття;

- коефіцієнт поточної ліквідності не менше величини, що дорівнює 2,0.

Але сам баланс дає картину діяльності підприємства в статиці, побачити ж її в динаміці дозволяє звіт про прибутки і збитки / доходи і витрати, застосовувані в його рамках методи.

В ринковій економіці витрати прийнято поділяти на постійні (або умовнопостійні) і змінні. Перші з них означають «витрати, сума яких не змінюється при зміні виручки від реалізації продукції» і включають в себе орендну плату, витрати 3 утримання будівель і відрахування на ремонт, амортизацію основних фондів i нематеріальних активів, відсотки за користування кредитами, страхові виплати та ін. Змінні витрати «це витрати, сума яких змінюється пропорційно зміні обсягу виручки від реалізації продукції», вони включають витрати на сировину, матеріали, електроенергію, оплату праці - всі параметри забезпечення самої виробничої сфери [9, с. 376)]. Така класифікація дозволяє здійснювати аналіз динаміки витрачання коштів, а також обчислювати точку беззбитковості для кожної конкретної ситуації, обумовлюваної обсягом виробництва. 
Точка беззбитковості обчислюється як в грошових одиницях, так і в формі коефіцієнта використання виробничих потужностей, що характеризує рівень їх використання, при якому зрівнюються витрати на виготовлення і надходження від реалізації продукції $[10$, с. 94)]. Точка беззбитковості є також надійнимй орієнтиром в оцінюванні ризику підприємницької діяльності і обчислюватися може як аналітичним, так і графічним способом.

Виробничі витрати визначаються кількістю виробленої продукції (або обсягом iii реалізації) і складаються, як зазначалося раніше, з постійних або функціональних витрат, що не залежать від обсягу продукції і змінних, пропорційних цьому обсягу. У деяких випадках доцільно орієнтуватися на власні дані минулих років, які мають право розглядатися як найбільш типові, але це не виключає можливості отримання таких даних іншими методами. Виробничі витрати (Вв) можуть бути виражені наступною формулою:

де Пв - постійні витрати;

$$
\mathrm{Bв}=\text { Пв }+ \text { Вв } \cdot 0 \text {, }
$$

Зв - змінні витрати на одиницю продукції;

$\mathrm{O}$ - обсяг реалізованої продукції.

Таким чином, точка беззбитковості, в деяких випадках звана «мертвою точкою», визначається порівнюванням виробничих витрат (Вв) і вартості продукції (Вп), яка виражається як добуток ціни (Р) та обсягу продукції (O).

$$
\mathrm{P} \cdot \mathrm{O}=\mathrm{BB} \text {. }
$$

Звідси стає можливим визначити той обсяг продукції $(\mathrm{O})$, який необхідно зробити, щоб не залишитися в збитку, і знайти ту «мертву точку», минувши яку підприємство починає отримувати прибуток.

$$
\mathrm{O}=\frac{\Pi_{\mathrm{B}}}{\mathrm{P}-3 \mathrm{~B}} \text {. }
$$

Завдяки такому співвідношенню-постійних витрат, віднесених до різниці між ціною одиниці продукції і змінних на неї витрат, можна не тільки обчислювати власну точку беззбитковості, починаючи з якої виробництво стає рентабельним, але і за допомогою варіювання цифрами досягати найбільш оптимальних умов функціонування і розвитку підприємства.

При використанні графічних розрахунків точка беззбитковості визначається за допомогою перетину двох прямих - виручки від реалізації (Вп) і виробничх витрат (Вв). При прогнозуванні планових показників графічно можуть бути відображені варіанти «найгіршого», «найкращого» і «найбільш ймовірного» плану, що дозволяє контролювати ситуації в напрямку більшої стійкості діяльності. Слід зазначити, що припущення про існування лінійної залежності виручки від реалізації та собівартості продукції від іï обсягу спростовуються численними дослідженнями. В реальності графічне представлення цих параметрів діяльності носить криволінійний характер. I область доходу має свої обмеження, тобто при досягненні деякого обсягу виробництва подальше його нарощування стає неефективним.

При складанні звіту про рух грошових коштів враховується ліквідність підприємства, здійснюється розрахунок оптимального рівня грошових коштів, а також аналіз відхилень фактичних результатів діяльності щодо прогнозних звітів про прибутки і збитки і звітів про рух грошових коштів, виявлення і своєчасне усунення яких також забезпечує стійкість функціонування підприємства. Додатковим інструментом фінансового контролю тут може бути аналіз відхилень на поточну дату, за допомогою якого відстежується динаміка «фінансових стрибків» і робляться дії по їх «згладжуванню». Наявність або відсутність у підприємства грошових коштів не 
завжди безпосередньо пов'язано з його прибутковістю, і це, зокрема, підтверджує загострення останнім часом проблеми взаємних неплатежів. У сучасних умовах нерідкі випадки, коли у прибуткового підприємства (за даними бухобліку) відсутні в наявності грошові кошти.

Визначення оптимального запасу грошових коштів, які необхідно зберігати у власній касі і на розрахунковому рахунку банку, можна проводити з використанням різних моделей, але не всі вони застосовні в умовах перехідної економіки з їі високим рівнем інфляції, нерозвиненості ринку цінних паперів та іншими факторами. Більш прийнятною представляється модель Міллера-Орра, яка відносно проста у використанні, але разом з тим дає можливість враховувати випадкові і значні коливання у витрачанні i надходженнях коштів, що характерно для сучасних російських умов. Вона надає способи управління запасами, навіть якщо важко більшменш регулярно передбачати відтік і приплив грошових коштів. Для реалізації цієї моделі експертним шляхом встановлюється деяка величина грошових запасів, яку представляється доцільним мати на рахунку. Потім, використовуючи власні статистичні дані, визначається варіація щоденних надходжень коштів на розрахунковий рахунок, враховуються витрати по їх зберіганню в банку, по взаємній трансформації цінних паперів і грошових коштів і здійснюється розрахунок розмаху варіації залишку грошових коштів [11, с. 317] на рахунку (S) за формулою:

$$
\mathrm{S}=\sqrt[3]{\frac{3 \cdot \mathrm{B} \cdot \mathrm{V}}{4 \cdot \mathrm{BT}}}
$$

$\mathrm{V}$ - варіація щоденних надходжень коштів на банківський рахунок;

Вз - витрати зі зберігання коштів на розрахунковому рахунку;

Вт - витрати по взаємній трансформації грошових коштів і цінних паперів.

Далі проводиться розрахунок верхньої межі запасів грошових коштів (ГКв) і точки повернення (Тп), до якої слід повернутися при виході залишку коштів за межі допустимого інтервалу. Нижньою межею (ГКн) вважається встановлена раніше експертним шляхом мінімальна величина запасів.

$$
\begin{gathered}
\Gamma К_{\mathrm{B}}=\Gamma \kappa_{\mathrm{H}}+\mathrm{S} ; \\
\mathrm{T \Pi}=\Gamma \kappa_{\mathrm{H}}+\frac{\mathrm{S}}{3} .
\end{gathered}
$$

Ефективність діяльності підприємства залежить від впливу внутрішніх та зовнішніх факторів. Усунення їх в повній мірі для підприємців найближчим часом неможливо, i причини того доволі об'єктивні. Але в рамках конкретного підприємства, за умов використання різних форм і методів фінансового планування, стає реальним. Зовнішні фактори та причини їх виникнення теж $є$ не менш значимими. Зменшення їх впливу можна здійснювати заходами економічного та організаційного характеру.

Висновки. Бізнес-план містить в собі фактично всі сторони діяльності підприємства, включаючи економічний, соціальний, організаційний та інші аспекти. Кожен $з$ цих аспектів діяльності має свої особливості і специфіку відображення в бізнес-плані, яка визначається конкретними завданнями діяльності підприємства як в цілому, так і окремих підрозділів, що забезпечує його повнокровне функціонування.

Так, в період економічної та фінансової стабільності на перший план виходять соціальні та організаційні напрямки діяльності фірми. У період зміни концепції, діяльності домінують питання побудови нової організації бізнесу і зміни його управлінських критеріїв. Але, навіть грамотно складений фінансовий план не гарантує успіх підприємницької діяльності в умовах перехідної економіки, де може істотно зростати величина ризику. Тому особливої значущості і подальшого дослідження 
потребує аналіз ризиків, який вимагає знаходження іншого підходу, обгрунтування виникнення тих чи інших ризиків та реальна оцінка ступеня ризику після прийняття всіх можливих заходів щодо його зменшення.

\section{СПИСОК ВИКОРИСТАНИХ ДЖЕРЕЛ}

1. Македон В. В. Бізнес-планування: Навч. пос. - К.: Центр учбової літератури, 2009. $236 \mathrm{c.}$

2. Фінанси підприємств: навч. посібник / за ред. Г. Я. Аніловської, І. Б. Висоцької. Львів: ЛьвДУВС, 2018. 440 с.

3. Бізнес-план: технологія розробки та обгрунтування: Навч. посібник. - Вид. 2ге, доп. / С. Ф. Покропивний, С. М. Соболь, Г. О. Швиданенко, О. Г. Дерев'янко. K.: KHEУ, 2002. - 379 c.

4. Економічний аналіз: Навч. посібник / М. А. Болюх, В. 3. Бурчевський, М. I. Горбаток та ін.; За ред. акад. НАНУ, проф. М. Г. Чумаченка. - Вид. 2-ге, перероб. і доп. - К.: КНЕУ, 2003. - 556 с. [Електронний ресурс]. - Режим доступу: https://ageofbook.com/study-materials/economic-theory/2967-ekonomchniy-analz-bolyuh-ma.html

5. Грабовецький Б. С. Економічний аналіз: Навчальний посібник. - К.: Центр учбової літератури, 2009. - 256 с. [Електронний ресурс]. - Режим доступу: http://pfor.com/book_153.html

6. ЗУ про внесення змін до Кодексу України з процедур банкрутства. Документ 686IX, чинний, поточна редакція - Прийняття від 05.06.2020 [Електронний ресурс]. - Режим доступу: https://zakon.rada.gov.ua/laws/show/2597-19\#Text

7. ЗУ Про внесення змін до Податкового кодексу України щодо вдосконалення адміністрування податків, усунення технічних та логічних неузгодженостей у податковому законодавстві Документ 466-IX, чинний, поточна редакція - Прийняття від 16.01.2020 [Електронний pecypc]. - Режим доступу: https://zakon.rada.gov.ua/laws/show/466-20\#Text)

8. Лишиленко О. В. Бухгалтерський облік: Підручник / О. В. Лишиленко. - К: Центр учбової літератури, 2017. - $670 \mathrm{c}$.

9. Гетьман О. О., Шаповал В. М. Економіка підприємства: Навч. посіб. - 2-ге видання. - К.: Центр учбової літератури, 2010. - 488 с.

10. Должанський I. 3., Загорна Т. О. Бізнес план: технологія розробки. Навчальний посібник. 2-ге вид. - К.: Центр учбової літератури. - 2009 р., - 384 с.

11. Шимко, П. Д. Международный финансовый менеджмент : учебник и практикум для бакалавриата и магистратуры / П. Д. Шимко. - 2-е изд., перераб. и доп. - М. : Издательство Юрайт, 2014. - 494 с.

\section{REFERENCES}

1. Makedon V. V Business planning: Train. manual - K: Center for educational literature, 2009. $-236 \mathrm{p}$.

2. Finance of enterprises : textbook / ed. by G. Ya. Anilovskaya, I. B. Vysotskaya. Lviv: LvDUVS, 2018. - $440 \mathrm{p}$.

3. Business Plan: technology of development and justification: Train. manual. - View. 2nd, additional. / S. F. Pokropivny, S. M. Sobol, G. O. Shvydanenko, O. G. Derevyanko. K: KNEU., 2002. - 379 p.

4. Bolyukh M. A., Burchevsky V. Z., Gorbatok M. I. et al., Economic Analysis: textbook; edited by academician of the National Academy of Sciences of Ukraine, Professor M. G. 
Chumachenko. - View. 2nd, rework. and add. - K.: KNEU, 2003. - 556 p. [accessed 202012-07]. - Retrieved from: https://ageofbook.com/study-materials/economic-theory/2967ekonomchniy-analz-bolyuh-m-a.html

5. Grabovetsky B. E. Ekonomicheskiy analiz: Training manual [Economic Analysis: a textbook]. K: Center for educational literature, 2009, - 256 p. [accessed 2020-12-09]. Retrieved from: http://p-for.com/book_153.html

6. Law of Ukraine on amendments to the code of Ukraine on bankruptcy procedures. Document 686-IX, current, current version - adoption of 05.06.2020 [accessed 2020-12-12].

- Retrieved from: https://zakon.rada.gov.ua/laws/show/2597-19\#Text

7. Law of Ukraine on amendments to the tax code of Ukraine on improving tax administration, eliminating technical and logical inconsistencies in tax legislation document 466-IX, current, current version - adoption of 16.01.2020 [accessed 2020-12-15]. Retrieved from: https://zakon.rada.gov.ua/laws/show/466-20\#Text)

8. Lishilenko O. V. bookkeeping: Textbook / O. V. Lishilenko. K: Center for educational literature, 2017, $-670 \mathrm{p}$.

9. Getman A. A., Shapoval V. M. Ekonomika predprinimatelstva: Train. manual. - 2nd edition. K: Center for educational literature, 2010, - 488 p.

10. Dolzhansky I. Z., Zagornaya T. O. business plan: development technology. Training manual. 2nd ed. - K.: Center for educational literature. $-2009,-384$ p.

11. Shimko P. D. Mezhdunarodny finansovykh upravleniya : textbook and workshop for bachelor's and master's degrees / P. D. Shimko. - 2nd ed., rework. and add. M: Yurayt publishing house, $2014,-494 \mathrm{p}$. 